\section{$-$}

journal.phaselis.org

\title{
2014 Yılı Çalışmaları Işığında Phaselis Antik Kenti'nin Geç Antik ve Ortaçağ Mimarisi ile Kentsel Yapısı
}

\author{
From the 2014 Research: Evidence of the Late Antique and \\ Middle Age Architecture and City Planning of the Ancient \\ City of Phaselis
}

Yalçın MERGEN

open $\bigcirc$ access journals

PHASELIS: Disiplinlerarası Akdeniz Araştırmaları Dergisi'nde bulunan içeriklerin tümü kullanıcılara açık, serbestçe/ücretsiz "açık erişimli" bir dergidir. Kullanıcılar, yayıncıdan ve yazar(lar)dan izin almaksızın, dergideki makaleleri tam metin olarak okuyabilir, indirebilir, dağıtabilir, makalelerin çıktısını alabilir ve kaynak göstererek makalelere bağlantı verebilir.

PHASELIS: Disiplinlerarası Akdeniz Araştırmaları Dergisi uluslararası hakemli elektronik (online) bir dergi olup değerlendirme süreci biten makaleler derginin web sitesinde (journal.phaselis.org) yı boyunca ilgili sayının içinde (Volume I: Ocak-Aralık 2015) yayımlanır. Aralık ayı sonunda ilgili yıla ait sayı tamamlanır.

Dergide yayımlanan eserlerin sorumluluğu yazarlarına aittir. 


\title{
2014 Yılı Çalışmaları Işığında Phaselis Antik Kenti'nin Geç Antik ve Ortaçağ Mimarisi ile Kentsel Yapısı
}

\author{
From the 2014 Research: Evidence of the Late Antique and Middle Age Architecture \\ and City Planning of the Ancient City of Phaselis
}

\author{
Yalçın MERGEN*
}

Öz: Lykia Bölgesi, Erken Hıristiyanlık ve Ortaçağ Hıristiyanlık Dönemi çalışmalarında sağladığı yeni ve ünik veriler nedeniyle ön plâna çıkmaktadır. Özellikle Anadolu Erken Ortaçağ urbanistik çalışmaları açııından Lykia Bölgesi'nde elde edilen veriler bu öneme değer katmaktadır. Son yıllarda Phaselis antik kentinde söz konusu dönemlere ilişkin yapılan çalışmalarla kentsel yapıya dair ortaya çıkmaya başlayan ipuçları, Lykia Bölgesi'ndeki diğer çalışmalar arasında Phaselis'in hızla önemli bir yer almasına olanak sağlamaktadır. Phaselis'in hem kent merkezinde hem de teritoryumunda gerçekleştirilen yüzey araştırmaları, yerleşimin Erken Hıristiyanlık ve Ortaçağ kimliğini aydınlığa kavuşturabilecek mimarî ve kentsel öğelerinin önceki çalışmalarda işaret edildiğinden çok daha yoğun ve ayakta olduğunu göstermektedir. Değişen çağdaş arkeoloji teorisi çerçevesinde, yerleşim alanlarının hem uygarlık hem de kültür tarihi perspektifini içeren bir yöntemle ele alınması, urbanistik yaklaşımların ağırlık kazanması; çalışmaların çok katmanlı stratigrafik değerleri gözeterek gerçekleştirilmesini zorunlu kılmaktadır. Bu anlayışa dayalı olarak, Erken Hıristiyanlık ve Ortaçağ arkeolojisi açısından oldukça geniş bir repertuara sahip olan Phaselis'te yüzeyde görülebilen sivil, kamusal, dini ve benzeri mimari öğeler 2013 yılından itibaren yapılan çalışmalarla tespit ve tasnif edilmeye başlanmıştır. Hem kent merkezi hem de kentin teritoryumunda daha önce yapılan çalışmalar sırasında belgelenmemiş birçok yeni bulgu elde edilmiştir. Son yıllarda Phaselis antik kentinde Erken Hıristiyanlık ve Ortaçağ dönemlerini kapsayan çalışmaların kaynak sıkıntııını da gidereceği kanısındayız.

Anahtar sözcükler: Lykia · Phaselis · Erken Hıristiyanlık · Doğu Roma · Ortaçağ · Kent · Mimari

Abstract: The Lycia Region has come into prominence with the new and unique data that it has provided for studies of Early and Medieval Christianity. The data from this region provides significant value, in particular in terms of Early Medieval Anatolian urban studies. In recent years, as a result of studies geared towards these periods at the ancient city of Phaselis, ample indicative evidence has been found in respect to its urban structure, which has given increased significance to Phaselis within the Lycia Region. Field surveys conducted both in the urban center and within the territory of Phaselis have discovered architectural and urban elements that show the Early Christian and Medieval identity of the site is much more considerable, in terms of its density and much more intact, than has recorded in previous studies. Within the framework of developing modern archaeological theory, with the prerequisite of making studies taking into consideration multi-layered stratigraphic principles, due to the fact that settlements are examined through a method that includes not only the perspective of cultural history, but also the perspective of the history of civilization and in accord with this standpoint, since 2013, scholars have

* Öğr. Gör. Dr., Dokuz Eylül Üniversitesi, Güzel Sanatlar Fakültesi, Temel Eğitim Bölümü, Sanat Kuramları Anasanat Dalı, İzmir.ymergen68@gmail.com 
been working to determine, record and classify the religious, public and civil architectural elements that can be observed through surface surveys at Phaselis, with its wide repertoire in archaeological terms of Early Christian and Medieval structures. Many previously undocumented finds have been made in both the urban center and within the territory of Phaselis. We think the studies of the Early Christian and Medieval periods of the ancient city of Phaselis will be one of the factors to eliminate the problem of the lack of resources in this field.

Keywords: Lycia · Phaselis · Early Christian · East Roman · Middle Age · Urban · Architecture

Geleneksel olarak Doğu Roma kenti şeklinde adlandırılan ancak, Hellen ve Roma kültür ve uygarlıklarının da izlerini taşıyan kentsel - yapısal biçem ne yazık ki hala açıklama bekleyen bir alandır. Bu konuya Anadolu ve Anadolu dışından ışık tutabilecek yerleşim ne yazık ki çok az sayıda, Doğu Roma kenti üzerine eğilen araştırmacılar ise, parmakla sayılacak niceliktedir. MüllerWiener, Foss ve Brandes'ten başlayarak Saradi gibi önemli araştırmacılar, Geç Antik Dönem ve Doğu Roma kent planlamacııı̆ının ulaştığı sonucu, Roma kentinin çöküşü olarak işaret etmektedirler. Foss, ve Brandes ${ }^{1}$ bu durumu "polis'ten kastron'a dönüşüm" olarak tanımlamaktadır. Tam da bu noktada ve özellikle Anadolu'dan bazı kent örnekleri durumun pek öyle olmadığını göstermektedir. Bu kentlerin arasında Lykia Bölgesi'nin önemli yerleşimlerinden biri olan Phaselis de yer almaktadır.

Kent - planlama - mimari ilişkisi urbanistik çalışmaları açısından büyük önem taşımaktadır. Özellikle Doğu Roma kent planlamacılığına dair dönem kaynaklarının olmayışı, planlamacılığa ilişkin özgün ilkelerin ve 'Doğu Roma kentinin' fiziki tanımının arkeolojik kazılar aracılığı ile tespit edilebilmesi anlamına gelmektedir. 2013 yılından başlayarak gerçekleştirilen çalışmalar, Phaselis'in bölgedeki Kyaenai, Andriake, Olympos gibi sayılı örneklerle Erken Hıristiyanlık ve Ortaçağ kentinin dönüşüm, oluşum ve oryantasyonu hakkında önemli bilgiler içerdiğini göstermektedir.

2012 yılı öncesinde yapılan araştırma ve kazı çalışmaları çerçevesinde, Phaselis'in Geç Antikçağ ve Ortaçağ açısından çokça irdelenmediği kaynaklara dayalı olarak söylenebilir. Phaselis'te yapılan en kapsamlı çalışma $\mathrm{H}$. Schläger tarafından başlatılan ve ölümünün ardından, J. Schäfer tarafından sürdürülen 1968 ile 1970 yılları arasındaki çalışmalardır. Yüzey araştırması ve belgeleme açısından belirlenen bir yöntem çerçevesinde sürdürülen bu çalışmalar Phaselis hakkında yapılmış en kapsamlı yayını da içermektedir². J. Schäfer'in ardından kapsamlı ilk arkeolojik kazı çalışması ise, Bayburtluoğlu tarafından gerçekleştirilmiştir. Bayburtluoğlu çalışmalarını bildiriler ve raporlar halinde 1983 ve 1985 yılları arasında yayınlamıştır ${ }^{3}$. Ancak, bu araştırmalar neredeyse tamamen ve olasılıkla imkân kıııtlılı̆ından dolayı Phaselis'in Hellen ve Roma dönemlerine yönelik gerçekleştirilmiştir. Bu yüzden 2013 yılı ve sonrasında, Phaselis'in Geç Antikçağ ve Ortaçağ yerleşimine dair yapılan çalışmalar ilk olması nedeniyle önem kazanmaktadır.

2013 yılından itibaren devam ettirilen çalışmaların başında, kentin topografik planının sayısal ortamda hazırlanması gelmektedir ve bu çalışmalar sürmektedir (Fig. 3). Hem kentsel dokuyu hem de kent içinde ve çevresinde bulunan yapıların kentle ve birbiri ile olan ilişkisini saptamayı amaçlayan topoğrafya çalışmaları aynı zamanda, Phaselis'te yer alan Geç Antikçağ ve Ortaçağ yapı stokunu saptamak açısından da önemli bir işlev üstlenmektedir.

Söz konusu çalışmalar çerçevesinde ve özellikle 2014 yılı araştırma sezonunda elde edilen

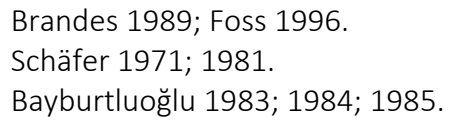


veriler, Phaselis'in Geç Antikçağ ve Ortaçağ'a tarihlenen kentsel yapısının neredeyse bütün bir biçimde saptanabileceğini göstermektedir. Bunun iki önemli nedeni bulunmaktadır. Bunların ilki: kent içinde ve çevresinde yer alan yapıların ve özellikle kentsel yapının çekirdeğini oluşturduğunu düşündüğümüz kamusal ve dinsel yapıların izlenebilir biçimde görece sağlam olarak günümüze ulaşmasıdır. Diğer neden ise; Phaselis'in Ortaçağ ve sonrasında biçimsel değişime neden olacak kentsel müdahalelere maruz kalmamasıdır. Zira kentte İslami bir yerleşimin izlerine rastlanmamaktadır.

Yapılan çalışmalar sırasında, Phaselis ve Lykia/Pamphylia Geç Antikçağ ve Ortaçağ Hıristiyanlık dönemlerine katkı sağlayabilecek ve literatürde bulunmayan yeni yapılar tespit edilmiştir. Bunlar, çalışmanın yöntemine bağlı olarak da iki ayrı biçimde irdelenebilir. Kentin akropolis'inde yer alan anıtsal boyutlardaki bazilikal planlı bir kilise, bu kilise ile bağlantılı ve akropolis'te bulunan yerleşimin tasarımına ilişkin veriler sunan sokak ve meydan düzenlemeleri, akropolis'te yer alan bir şapel ve bir adet orta ölçekli bazilikal planlı kilise; Phaselis kent merkezinde yapılan çalışmalar sonucunda tespit edilen mimari öğelerdir. Inciryalısı Mevkii'nde saptanan bazilikal planlı bir kilise ise, teritoryal çalışmalar çerçevesinde saptanmış ve değerlendirilmiştir. Söz konusu yapılar, hem fiziki hem de sayısal ortamda rölöve - restitüsyon çalışmaları gerçekleştirilerek belgelenmiştir.

\section{Kentsel Yapı}

Phaselis kenti, teritoryumu ile birlikte çok geniş bir alanda hakimiyet kurmuş gibi gözükmektedir. Kemer illçesi'nin Tekirova Beldesi'ne bağlı sınırlar içinde yer alan Phaselis'in teritoryal sınırları kuzeyde Gökdere Vadisi ile Akdeniz arasında kalan bir şerit boyunca uzanmaktadır. Bu şerit, batıda Üç Adalar, doğuda ise Çandır Vadisi'ni de içine alacak biçimde sınırlanmaktadır .

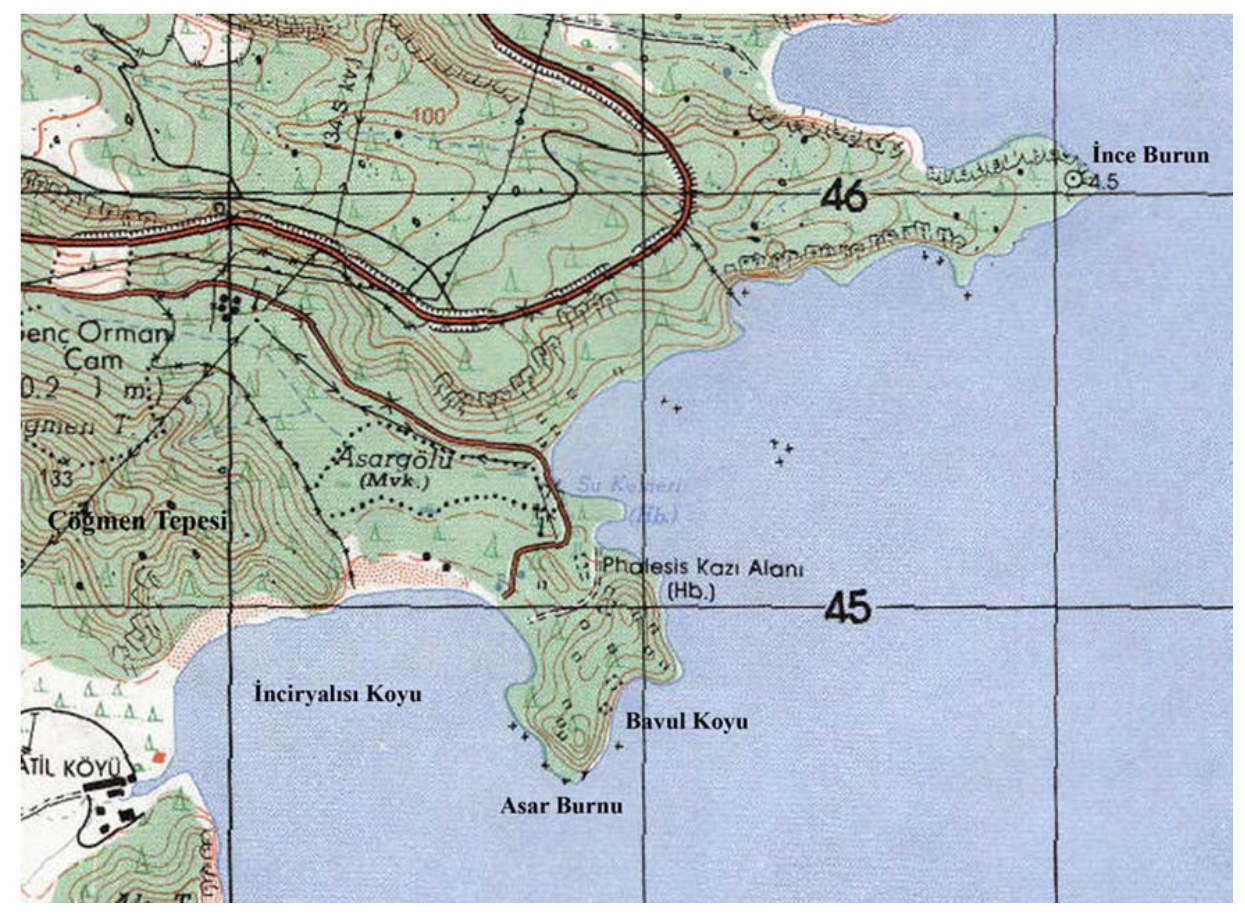

Fig. 1. Phaselis ve Çevresinde Yer Alan Coğrafik Öğeler

${ }^{4}$ http://www.phaselis.org/phaselis/kentin-konumu. 


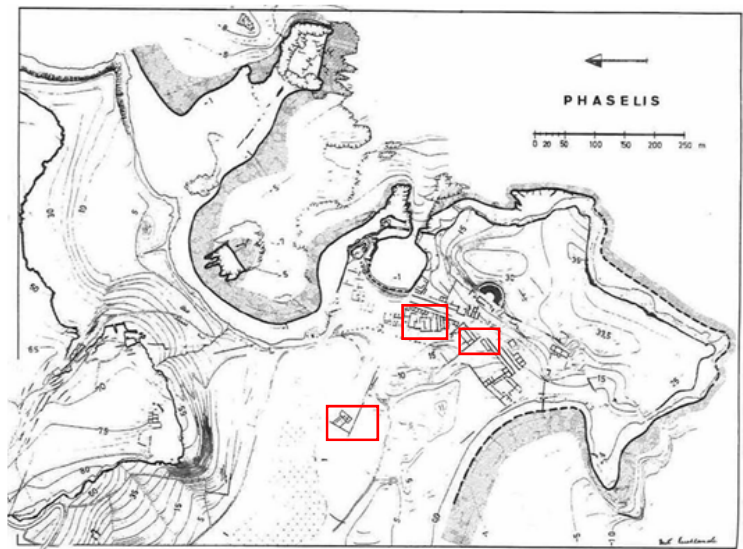

Fig. 2. Phaselis'te Bilinen Ortaçağ Yapıları (Schäfer'dan)

Henüz çalışmalar başlangıç aşamasında olmakla beraber, Phaselis'in okunabilir durumdaki kent planı ve kent merkezi ile teritoryumu arasında kurulabilen fiziki ilişki bu aşamada dahi önemli katkılar sağlamaktadır. Phaselis coğrafik konumu ve yapısı nedeniyle Lykia'nın Geç Antikçağ ve Ortaçağ kıyı kentleri ile benzer özellikler sergilemektedir. Kıyı Lykia Bölgesi'nin dik yamaçlı dağlık bir yapıya sahip olması ve Akdeniz'e kıyısı bulunması bu özellikleri belirleyen önemli etmenlerdir. Orta Çağ'da yaygın bir özellik olarak; Olympos, Patara, Phaselis gibi tüm Lykia liman kentlerinin kullanılabilir tarım arazileri bulunmamaktadır. Bununla beraber bu tür kentlerde yaşamın deniz yolculukları ve deniz ticaretine dayalı olarak sürdüğü bilinmektedir ${ }^{6}$. Lykia'nın diğer kıyı kentlerinde olduğu gibi Phaselis de çok geniş tarım arazilerine sahip olmasa da, deniz yolculuklarına ve ticaretine dayalı bir yaşam biçimini sağlayacak kıyı ve limanlara sahiptir (Fig. 13).

Yukarıda değinilen ve Lykia kentlerine özgü olarak değerlendirilen genel özelliklerinin dışında Phaselis, özgün ve ayırıcı bazı özelliklere de sahiptir. Bunların başında yüzeyde yer alan kalıntılar sayesinde söz konusu dönemlerde de kullanıldığı anlaşılan, üç farklı liman ${ }^{7}$ ve bu
Phaselis'in ana yerleşim merkezi ise, özgün bir coğrafik yapıya sahiptir. Kentin belirgin karakteristiğini oluşturan en önemli husus, akropolis olarak adlandırılan yarımada ve kentin nekropolis alanı ile kent merkezini ayıran Kuruçay'dır. Akropolis'in üzerinde yer aldığı yarımada, Ince Burun ile Asar Burnu arasındaki körfez ile Ala Tepe ile gene Asar Burnu arasında kalan Inciryalısı Koyu'nu birbirinden ayırmaktadır (Fig. 1-3). Bu nedenle Kentin kuzey ve güneyinde korunaklı iki koy oluşmuştur. Bu koylar mendirek ve dalgakıran düzenlemeleri ile Phaselis'in özellikle erken dönemlerinde liman olarak kullanılmıştır ${ }^{5}$.

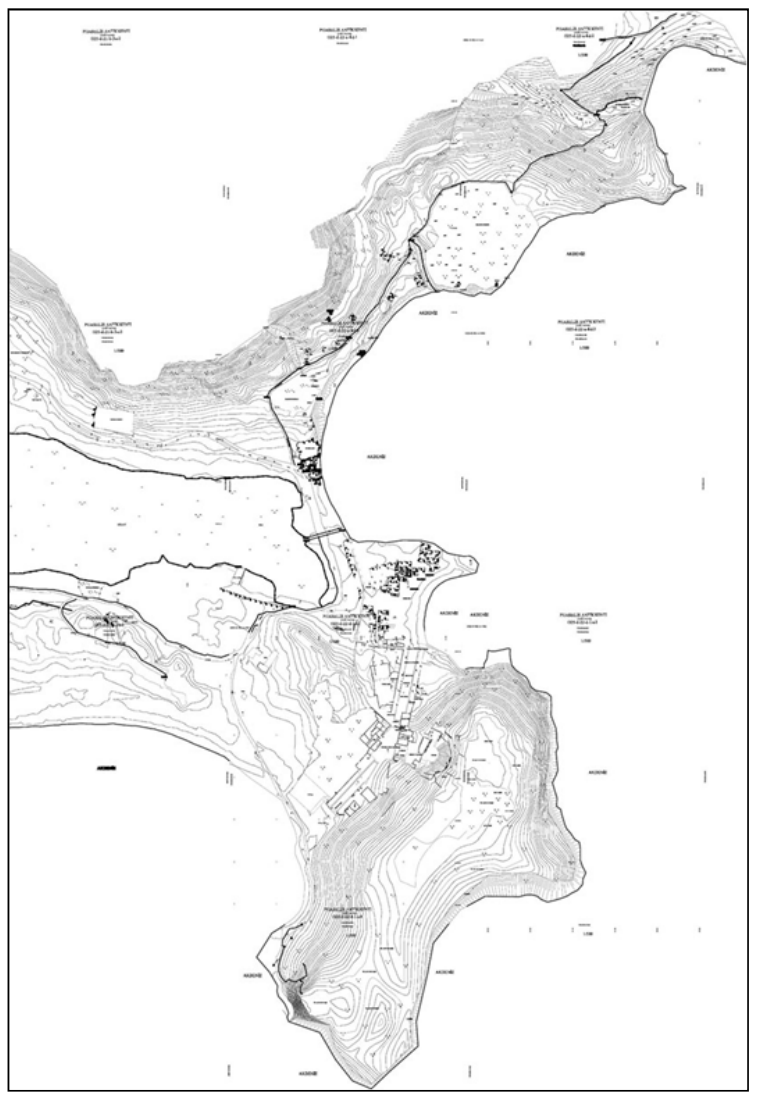

Fig. 3. Phaselis Antik Kenti Güncellenmiş Topografik Planı

\footnotetext{
Bilgi için bk. Schäfer 1981, 55-67.

Hild 2004, 3.

Bayburtluoğlu 1983, 182; Adak et al. 2005, 1.
} 
limanlardan kuzeydekine açıldığını şimdilik varsaydığımız bir gölet bulunmaktadır (Fig. 2-3).

2014 yılında sürdürülen çalışmalar çerçevesinde Geç Antikçağ ve Ortaçağ yerleşmesinin akropolis'te yoğunlaştı̆̆ı anlaşılmaktadır. Kuzey ve Güney limanları birbirine bağlayan cadde ve bu caddenin çevresindeki yapıların bu dönemde kentin kamusal alanlarını teşkil ettiği söylenebilir. Bunun nedeni özellikle Liman Caddesi'nin kuzeyinde ve batı kanadında yer alan hamamda Bayburtluoğlu tarafından yapılan çalışmalar sırasında elde edilen bulgulardır. Tiyatro hamamı olarak adlandırılan yapıdaki çalışmalar sonrasında Bayburtluoğlu bu binanın farklı işlevlerde de olsa Arap akınlarına kadar kullanıldığını aktarmaktadır ${ }^{8}$. Ayrıca, gene Bayburtluoğlu tarafından gymnasion hamamının palaestra zemininde mozaik zemin kaplaması açığa çıkarıımıştır. Bayburtluoğlu söz konusu mozaik kaplamada yer alan yapım kitabesine dayanarak', hamamın M.S. VI. yüzyıl civarında bir villa olarak kullanıldığını düşünmektedir ${ }^{10}$.

Yukarıda sayılanların dışında kentin bu bölgesinin kamusal alan olarak değerlendirilmesinin en önemli nedeni ise, tetragonal agora içerisinde yer alan üç nefli Hellenistik bazilika ve hem hamam hem de agora'da görülen, duvar teknikleri nedeniyle Roma Dönemi inşa malzeme ve tekniğinden farklılık gösteren mekânlardır. Hem önceki araştırmaların ışı̆̆ında hem de söz konusu malzeme teknik özellikler nedeniyle bu mekânların Ortaçağ yapılarına ait olduğunu düşünmek mümkündür. Henüz detaylı bir çalışma yapılmamış olmakla beraber, tetragonal agora içinde inşa edilmiş olan bazilikal planlı kilise, plan özellikleri, proporsiyonları, örtü sistemi ve malzeme teknik özellikleri açısından Lykia Bölgesi'nde M.S. VI. yüzyıl civarına tarihlenen birçok örnekle benzerlik göstermektedir ${ }^{11}$. Kilisenin bu alandaki varlığına dayalı olarak da söz konusu geç

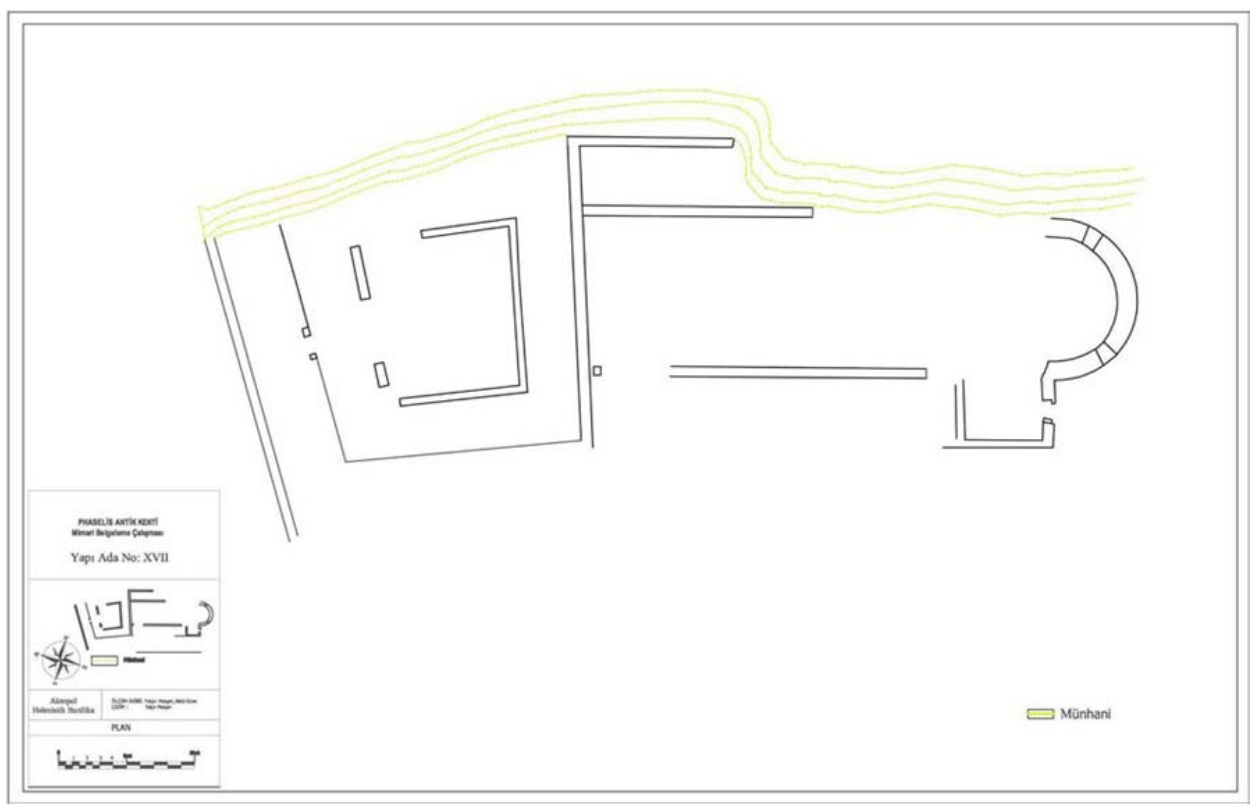

Fig. 4. Akropolis 1 no'lu Kilisenin Planı

8 Bayburtluoğlu 1983, 185.

9 Bayburtluoğlu 1985, 376, 384 res. 13.

10 Bayburtluoğlu 2004, 90-91.

11 Benzer örnekler için bk. Gemiler Ada I, II, III ve IV no'lu kiliseler, Ölüdeniz Kumsal Bazilikası, Ölüdeniz Lagün Bazilikası, Besta Koyu Kilisesi. A. Kazuno 1995, 407-419. Ksanthos Akropolis Kilisesi, Canbilen et al. 1996, 201-229, Ksanthos Büyük Bazilika, Sodini 1980, 119-148; Patara Büyük Kilise, Işık 1995, 253-282. Olympos 1 no'lu kilise; Gökalp - Yıldırım 2010, 367-387. 
dönem duvarlarının en azından M.S. VI. yüzyıl ve sonrasında inşa edilmiş olabileceğini söylemek yanlış olmayacaktır.

Henüz sonuca ulaşmamış olmakla beraber, akropolis'te yapılan yüzey çalışmaları bu mevkiinin de Ortaçağ'da iskân edildiğini göstermektedir. Akropolis'teki yapı yoğunluğundan kaynaklı olarak, Phaselis'in sivil yerleşme alanının akropolis olduğu anlaşılmaktadır. Ayrıca Schäfer tarafından tespit edilen küçük boyutlu bir şapele ${ }^{12}$ ek olarak 2013 yılında yapılan çalışmalar sırasında ortaya çıkarılan ve birisi belgelenen dört adet kilise de bu kanıyı doğrulamaktadır. Bu toplam sayı sonuç olmamakla beraber geniş bir alana sahip akropolis'teki bu kiliselerin olasılıkla mahalleleri temsil ettiği anlaşılmaktadır. Bu kanıyı doğrulayan en önemli veri ise, kiliselerde ve çevrelerinde yer alan sarnıçlardır. Büyük boyutlu ve farklı tiplerdeki bu sarnıçların bazıları konut olduğunu düşündüğümüz, birden çok kat düzenlemesine sahip mekânların içinde ve/veya avlularında bulunmaktadır. Simetrik veya diyagonal simetrik biçimde bir avlunun içine yerleştirilmiş organik biçimde ilişkili kapalı mekânlar, işlevlerine göre bir ya da birden çok katlı inşa edilmişlerdir. Bu yapıların bazıları arasında dar sokak bağlantıları izlenebilmektedir. Benzer biçimli bir planlama Olympos Akropolis Tepesi'nde de bilinmektedir ${ }^{13}$.

\section{Akropolis I no'lu Bazilikal Planlı Kilise, Giriş ve Meydan Düzenlemesi:}

a- I no'lu Kilise:

Akropolis Doğu Roma Hıristiyanlık Dönemi । no'lu Bazilikal Plânlı Kilise'si Phaselis antik kenti akropolis'inin güneyinde, deniz seviyesinden

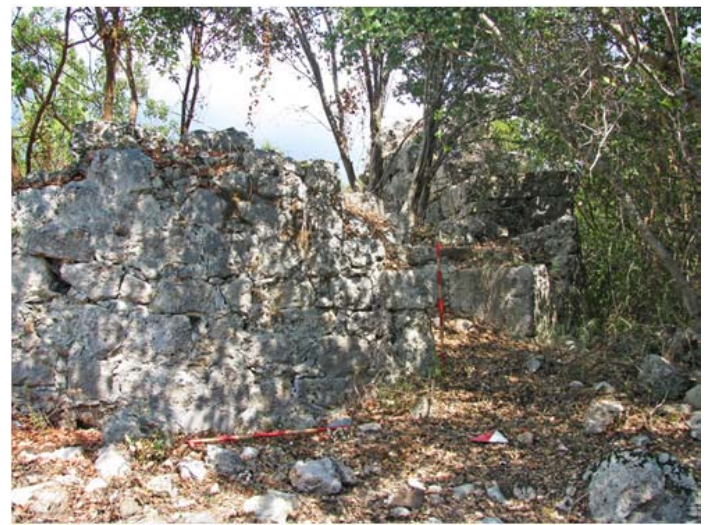

Fig. 5. 1 no'lu Kilise Apsis Dış Cephe

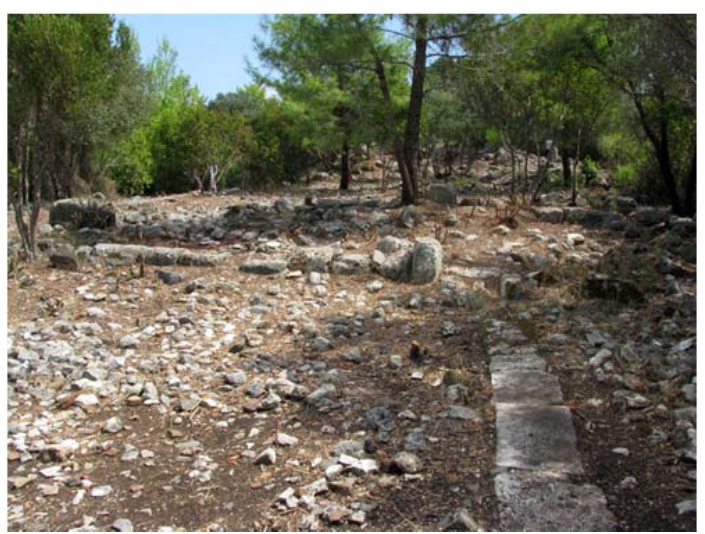

Fig. 6. 1 no'lu Kilise Atrium ve Naos, Doğuya Bakış

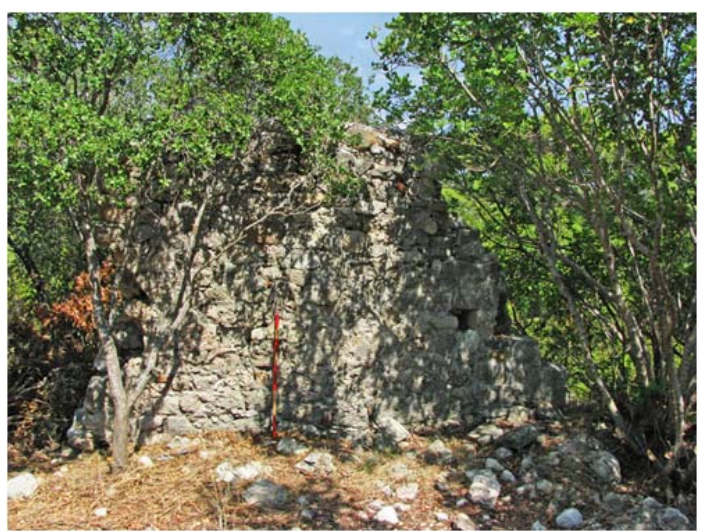

Fig. 7. 1 no'lu Kilise Kuzey Nef Duvarı, Iç Cephe yaklaşık 25 metre yükseklikte Akdeniz ve Güney Liman'a hâkim bir konumda yer almaktadır. Kilise, güneyde ve batıda olasılıkla daha erken dönemde istinat duvarları ile güçlendirilmiş bir düzlük üzerinde bulunmaktadır. Yapının avlusuna (atrium) ait güney ve batı duvarları ile gene avlu ve ana mekânına (naos'una) ait güney cephe duvarları söz konusu istinat duvarları üzerine inşa edilmiştir (Fig. 10). İstinat duvarlarının desteklediği dik eğimli yamaç kilisenin, güneydeki doğal sınııını oluşturmaktadır (Fig 10). Yapının ku-

12 Schäfer 1981, 122.

13 Mergen 2011, 462-489. 


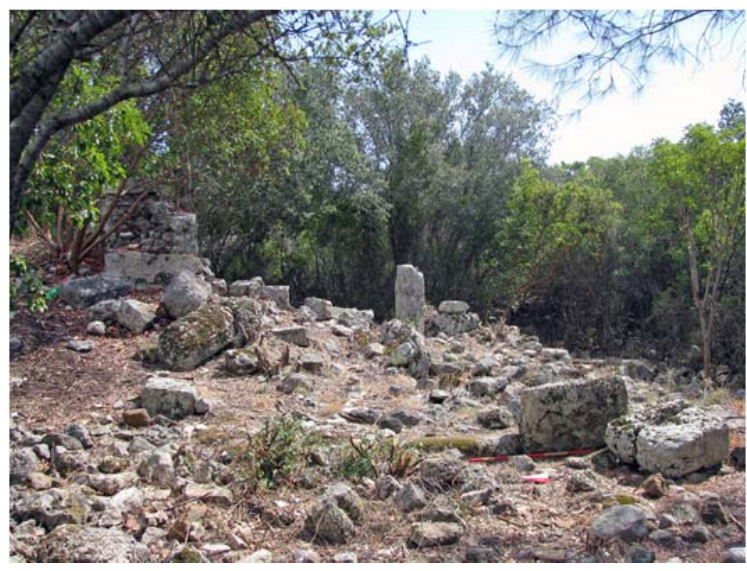

Fig. 8. 1 no'lu Kilise Güney Transept Kolu ve Güney Nef, Doğuya Bakış zeyinde yer alan büyük boyutlu bir sarnıç dışında ve cephe duvarlarının temel izlerinden başka bir veriye şimdilik ulaşılamamıştır. Bu nedenle yapının kuzeydeki yayılım alnının sınırları henüz tespit edilememiştir. Kilise doğu-batı doğrultusunda toplam 62.30 metre kuzey-güney doğrultusunda ise, 22.75 metre boyutlarında bir alana yerleşmektedir. Yapının ana mekânı doğu-batı doğrultusunda 40.50 metre, kuzey-güney doğrultusunda ise 22.75 metre ölçülerine sahiptir (Fig. 9).

I no'lu Kilise, doğu batı yönünde uzunlamasına yöneliş gösteren üç nefli transeptli bazilikal plân şemasına sahiptir ${ }^{14}$. Kilisenin batı-

sında oldukça geniş bir alana yayılan atrium bulunmaktadır. Atrium'un sütunlu bir düzenlemeye sahip olduğu stilobat kalıntılarından anlaşılmaktadır (Fig. 4, 6, 9 ). Duvarlar temel seviyesine kadar tahrip olduğundan giriş açıklıkları görülememektedir (Fig. 6, 8.) Yapının atrium'undan üç nefli olduğu stilobat kalıntılarına dayalı olarak anlaşılan noas'una batı yönü açık sundurmalı bir narteks'le giriş sağlanmaktadır. Kilisenin güney nefi ve güneyde olması beklenen transept kolu güney istinat duvarlarının çökmesine bağlı olarak tamamen tahrip olmuştur (Fig. 7). Kilisenin doğusunda ise içten ve dıştan yuvarlak plânlı bir apsis yer almaktadır. Apsis üzerinde iki adet büyük boyutlu mazgal pencere görülmektedir (Fig. 5, 9). Yapının ana mekânına girişi sağlayan kapılardan birisi apsis cephesinde ve kuzey transept kolunda yer almaktadır. Diğer giriş açıklığı ise, ana nefin batısında olmalıdır. (Fig. 8, 9).

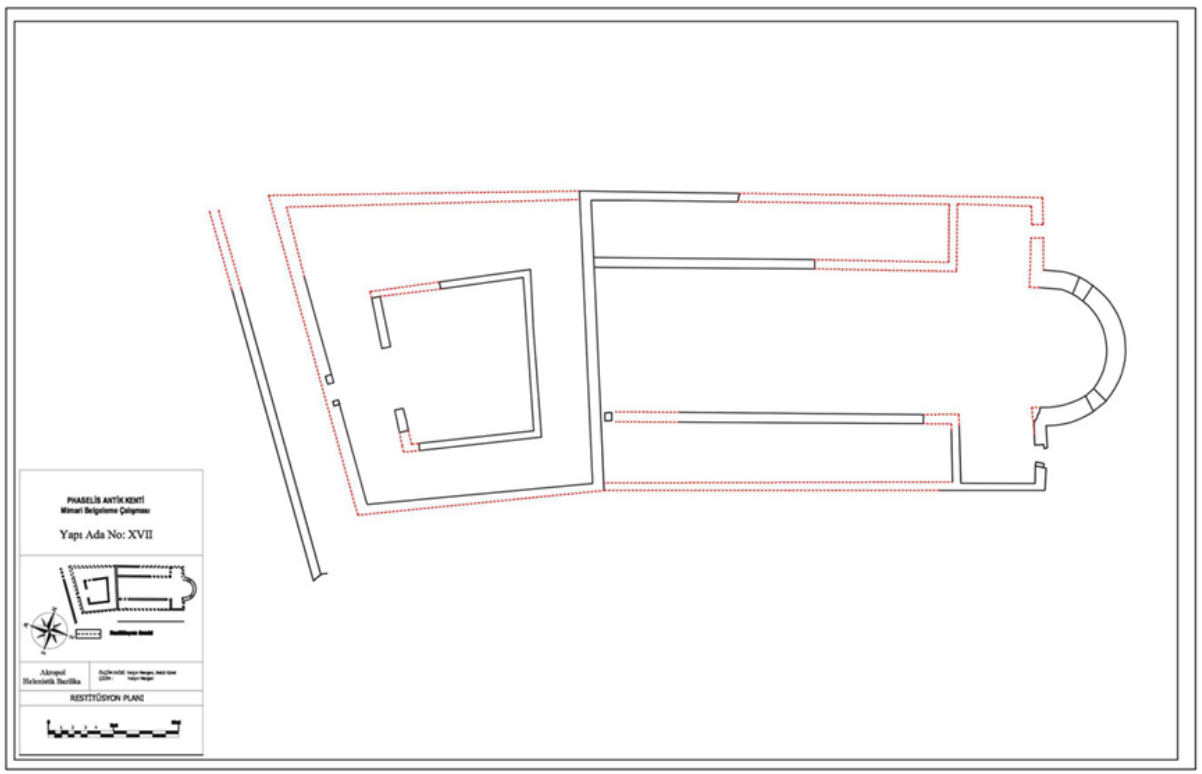

Fig. 9. Akropolis 1 no'lu Kilisenin Restitüsyon Planı

14 Şu ana kadar elde edilen verilere göre bazilika, Krautheimer'in $(1969,59)$ tipolojisinde "Haç Transept" içerisinde yer almaktadır. 


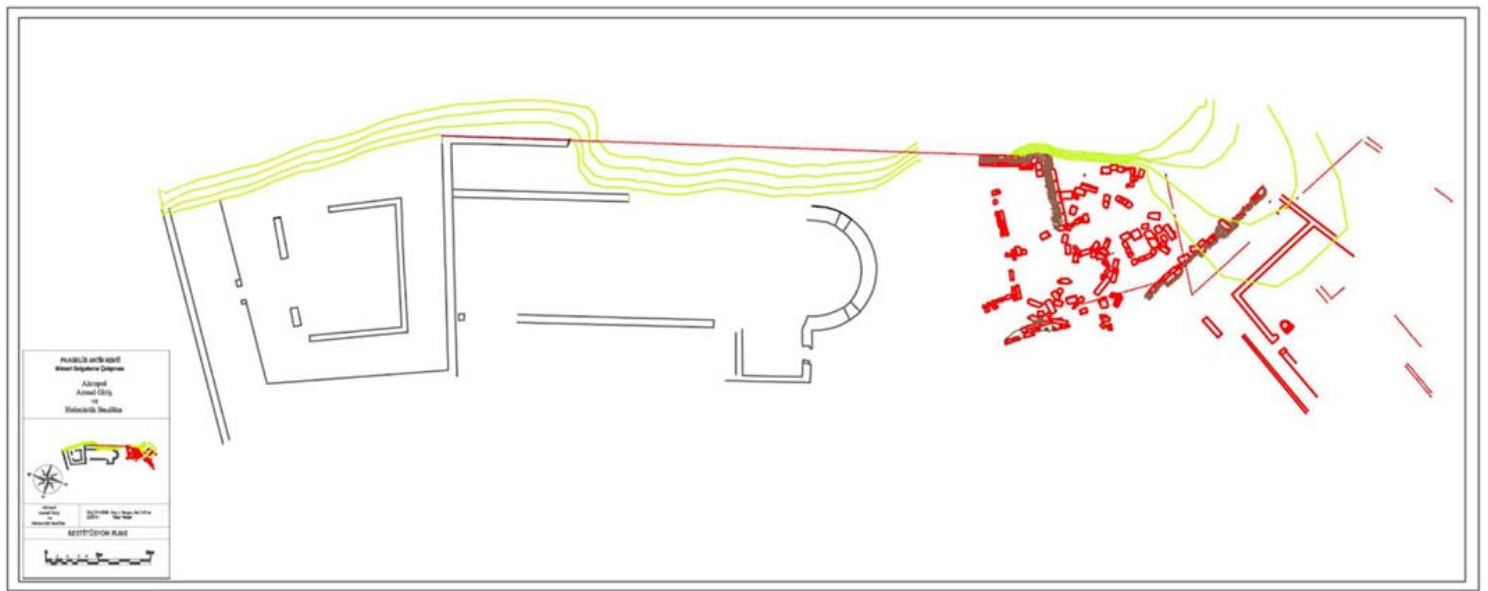

Fig. 10. Akropolis Meydan Düzenlemesi Taş Planı

Yapı günümüze sağlam ulaşamamıştır. Apsis ve güney cephe duvarının batı bölümündeki bir parçanın dışında duvarlar temel seviyesine kadar yıkıktır. Kilisenin ana mekânının kuzey batı dış köşesine çok yakın bir konumda ise, olasılıkla atriumla da bağlantısı bulunan ve doğu kısmı duvarla çevrili olduğu anlaşılan büyük bir sarnıç görülmektedir. Söz konusu sarnıç Phaselis akropolis'inde sıklıkla rastlanan içi sıvalı sarnıçlarla boyut ve yapısal olarak uyum göstermektedir.

Kilisenin inşasında genellikle, kaba - yontu kesme taş ve moloz taş kireç harcı bağlayıcı malzeme kullanılarak uygulanmıştır. Bunun dışında apsis'te görülen örnekler ışığında daha erken dönemlere ait devşirme malzeme de kullanıldığı anlaşımaktadır. Kilisenin naos'unda rastlanan bazı örnekler çerçevesinde ahşap örtü sisteminin devşirme sütunlarla taşındığı gözlemlenmektedir.

Lykia ve Bölgesi'nde transeptli bazilikal plan şemasında inşa edilmiş örnekler Hellenistik bazilikal plan şemasında inşa edilmiş örneklere göre daha az sayıdadır. Bununla beraber Tlos ${ }^{15}$, Pata$\mathrm{ra}^{16}$, Limyra ${ }^{17}$ ve Olympos'ta ${ }^{18}$ transeptli ve üç nefli bazilikal plânlı kiliseler bulunmaktadır.

Doğu Roma mimarisinde M.S. IV.-VI. yüzyıllar arasında kullanılan transeptli bazilikaların Anadolu'daki örnekleri M.S. V.-VI. yüzyıllar içerisinde değerlendirilmektedir. Ayrıca, Lykia Bölgesi'nde, iyi korunmuş bir örneği Korba'da ${ }^{19}$ bulunan ve naos'un doğusunda apsis önünde yer alan transeptin, kuzey ve güneyde yarım daire apsislerle sonlandığı örnekler bilinmektedir. Bu örneklerden başka, Aperlai, Muskar ve Çamarkası'nda da transeptli bazilikalar yer alır ${ }^{20}$. Ancak bu kiliseler transeptli ve üç nefli olmaları dışında Phaselis örneği ile başka açıdan benzerlik

15 Tlos'ta bulunan kilisede 2014 çalışma sezonunda çalışmalara başlanmış olsa da bu makalenin yazıldığı sırada yeni bir yayın yapılmamıştır. Bu nedenle kilisenin planı Wurster'in (1996, 161-174, 167 abb. 4) kent planında görülebilmektedir.

16 Uluçam 1991, 29-55, 37-38 çiz. 8-53; Effenberger - Kunze 1995, 253-282 çiz. 1.

17 Tam bir planı henüz yayınlanmamış olan kilisede naos'un doğusunda, apsis önünde kuzey-güney yönünde bir transept bulunmaktadır (ayrıca bk. Peschlow 1984, 411 abb. 1).

18 Mergen 2011, 382-387.

19 Geppert 2000, 33-39, 34 abb. 19; Altripp 2006, 75-88.

20 Aperlai antik kentinde yer alan kiliseler sadece kent plânı içerisinde yayınlanmıştır (Peschlow 2007, 613, 624). Aperlai için ayrıca bk. Vann et al. 2001, 286. Muskar ve Çamarkası kiliselerinde transept kolları apsidal formda sonlanmaktadır. Konuya ilişkin olarak ayrıca bk. Grossmann - Severin 2003, 27-33, 116-118. Altripp 2006, 75-88. 


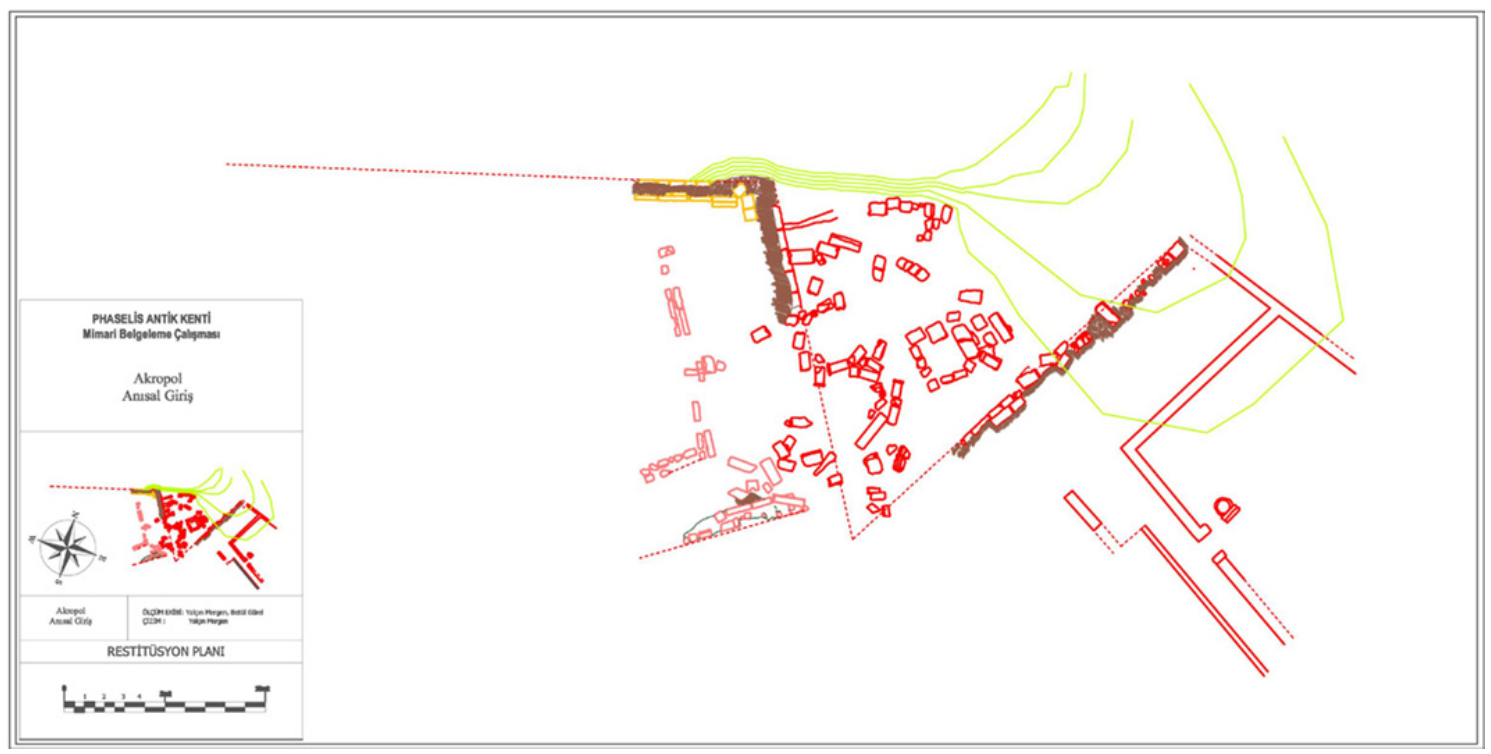

Fig. 11. Akropolis Meydan Düzenlemesi Taş Planı

göstermezler. Genel bir yaklaşımla iki transeptli bazilikaya sahip kentler bölgelerin metropolit kentleri ya da önemli merkezleri olarak yorumlanmaktadır. ${ }^{21}$

Bu plan tipi, Lykia Bölgesi dışında Pamphylia'da Perge ${ }^{22}$ ve Side'de M.S. V.-VI. yüzyıllara tarihlenen, Piskoposluk Bazilikası'nda uygulanmıştır. ${ }^{23}$ Diğer yandan Side'deki Piskoposluk kilisesi de Olympos'taki kilise gibi yüksek duvarlarla çevrelenmiştir. ${ }^{24}$

\section{b- Meydan Düzenlemesi:}

Söz konusu alan Phaselis akropolis'inin yaklaşık güney doğusunda, Güney Liman'ın hemen üzerinde, 1 no'lu kilisenin hemen doğu- kuzeydoğusunda ve yaklaşık 26 metre rakımda yer almaktadır. Çok yoğun kesme ve moloz taş yıkıntının gözlendiği alan, güneybatıda I no'lu kilisenin güney cephe duvarlarının da üzerine yerleştirildiği teras duvarının başlangıcı ile sınırlanmaktadır. Batıda Phaselis'in erken dönem duvar iş̧̧iliği ve malzemesi ile uyum gösteren, olasılıkla anıtsal bir yapıya ait duvarlar bulunmaktadır. Kuzeyde ise diğer yapılarda olduğu işlevi henüz belirlenemeyen mekanlar ve bir sokak, doğuda ise sık bitki örtüsü nedeniyle girilemeyen bir düzlük bulunmaktadir (Fig. 10-11).

İstinat duvarı, anıtsal yapı ve sokakla çevrelenmiş olan alanın en önemli özelliği batıda yaklaşık kuzey-güney, kuzeyde ise yaklaşık doğu-batı doğrultusunda uzanan dar açıyla birleşen iki farklı krepidoma ile düzenlenmiş olmasıdır (Fig. 11). Kuzeyde izlenen krepidomanın iki krepisli olduğu anlaşılmakla birlikte batıda yer alan krepidomanın yıkıntı ve toprak altında kalmasından dolayı kaç krepis'li olduğu anlaşılamamaktadır.

Bu alanda yapılan çalışmalar sırasında oldukça fazla sayıda; ancak yangın nedeniyle büyük oranda tahrip olmuş mimarî plâstik ve yapı malzemesine rastlanmıştır. Belgelenen bu malzeme-

\footnotetext{
21 Iki transeptli kiliseye sahip kentlerden Side ve Perge, Pamphylia Bölgesi'nin metropolit merkezleridir. Aynı şekilde Pisidia Bölgesi'nin önemli kentlerinden Antiokheia kentinde de iki transeptli bazilika bulunmaktadır.

22 Rott 1908, 47 abb. 19.

23 Mansel 1978, 267-269.

24 Mansel, 1978, 269 res. 299.
} 

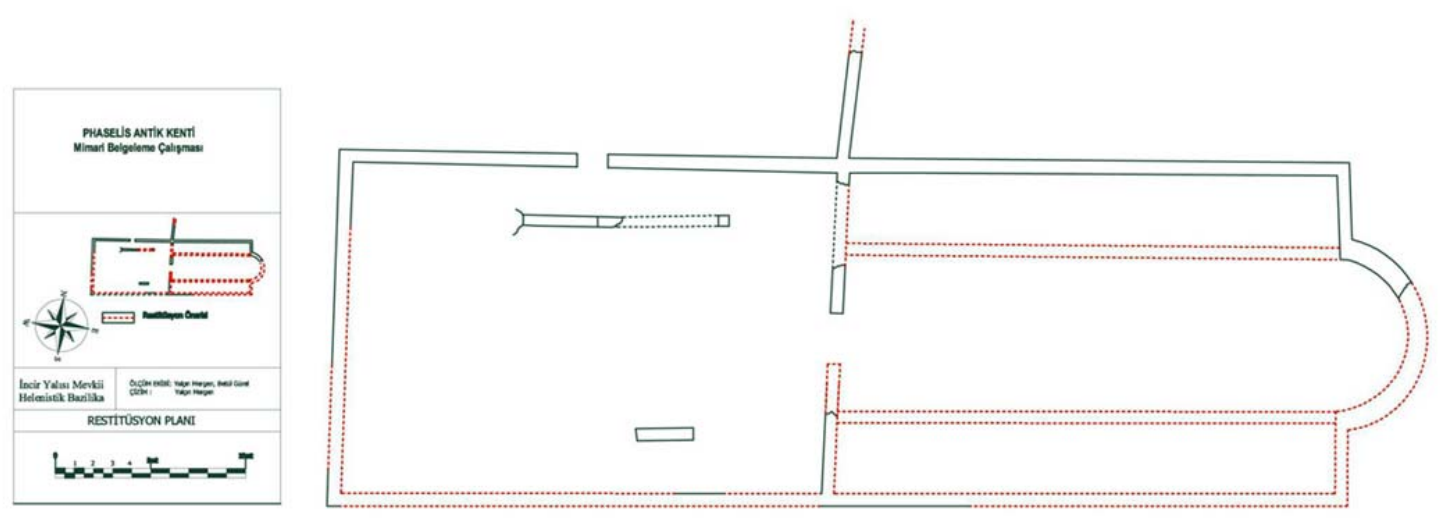

Fig. 12. Inciryalııı Bazilikası Restitüsyon Planı

lerin arasında özellikle yazıtlı bir arşitrava ait parçalar dikkat çekicidir.

Phaselis antik kenti teritoryumunda yapılan çalışmalar sırasında da bazı önemli sonuçlar elde edilmiştir. Bunların başında Inciryalısı Mevkii'nde tespit edilen ve literatürde bulunmayan, üç nefli Hellenistik bazilika gelmektedir.

\section{İncir Yalısı Kilisesi:}

Inciryalısı Koyu'nun yaklaşık kuzeydoğusunda, sahilde ve kıyı kenar çizgisine çok yakın bir mevkide yer alan yapı; Çöğmen Tepesi'nin güney yamaçları ile kıyı kenar çizgisi arasında kalan bir düzlükte inşa edilmiştir (Fig. 13). Yapı topluluğu yaklaşık 36³1'24.28"K ve 30³2'30.85"E koordinatlarında yer almaktadır.

Bu düzlük üzerinde ve yapının çevresinde izlenebilen duvar kalıntılarına ve yüzeyde dağılmış durumdaki moloz yığınlarına dayalı olarak kilisenin bir yapı topluluğunun içinde yer aldığını söylemek olanaklıdır. Ayrıca, gene yapı ve yakın çevresinde görülebilen nitelikli kesme-taş ve profilli mimari parçalardan dolayı kilisenin inşa edildiği alanda veya yakın çevrede Roma Dönemi'ne ait yapı ve/veya yapıların bulunduğunu düşünmek doğru olacaktır. Özellikle kilisenin batısında ve yaklaşık 200 metre batısında bulunan 36³1'19.86"K ve 30³2'25. 55"E koordinatlarındaki bir su kaynağı çevresinde görülebilen bloklar, tuğla, pişmiş toprak zemin kaplama ve benzeri yapı malzemeleri bu alanda bir ayazma olabileceğini düşündürmektedir (Fig. 13).

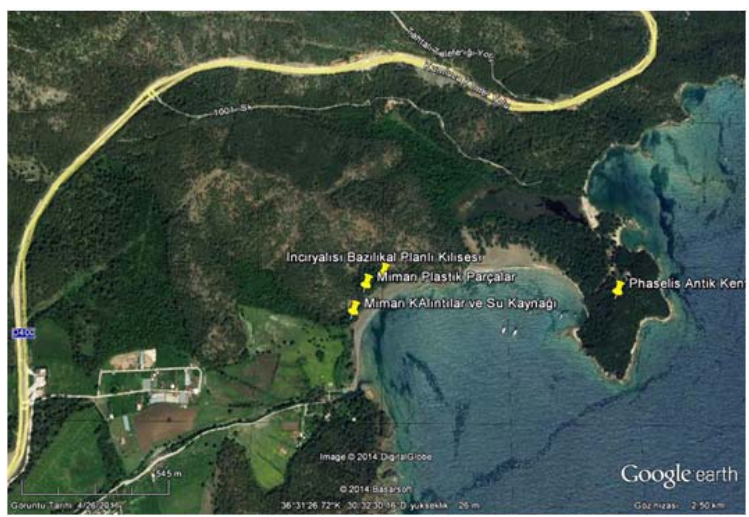

Fig. 13. Inciryalısı Mevkii Kilisesinin Phaselis Antik Kenti'ne Göre Konumu
Kilise:

Inciryalısı Mevkii'nde yer alan kilise, doğu batı doğrultusunda 57.40, kuzey güney doğrultusunda ise, yaklaşık 25.50 metrelik bir alanda inşa edilmiştir. Naos ve atrium'un konumlandığı bu alan çevresinde kuzeyde ve batıda moloz ve kesme taş yapı malzemeleri geniş bir alanda yayılım göstermektedir. Kilisenin naos'u doğu-batı doğrultusunda 31.45, kuzeygüney doğrultusunda ise, 18.25 metrelik ölçülere sahiptir (Fig. 12). 
Lykia Bölgesi Erken Hıristiyanlık ve Doğu Roma yapı tipolojisinin özelliklerini göstermektedir. Bölgenin M.S. V. ve VI. yüzyıllarında yaygın biçimde inşa edilen ${ }^{25}$ benzer örnekleri ile uyumlu bir plan tipine sahiptir. Kilise doğu-batı doğrultusunda uzanmaktadır. Dikdörtgen planlı ana mekâna ve mekânsal oranlara dayalı olarak kilisenin üç nefli Hellenistik bazilikal plan şemasına sahip olduğu anlaşılmaktadır (Fig. 12). Yapının apsis'i dıştan vurgulu içten ve dıştan yuvarlak planlıdır (Fig. 12, 14). Batı kııımda yapının ana mekânına oranla oldukça geniş bir atrium bulun-

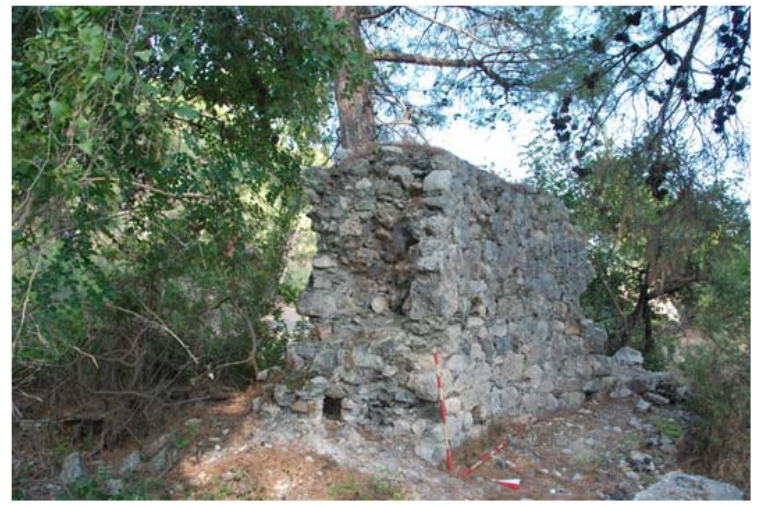

Fig. 14. Inciryalısı Bazilikası Apsis İ̧c cephe, Doğuya Bakış

maktadır. Nartekse dair bir iz görülememekle beraber atrium ve naos arasında yer alan bir koridorun narteks işlevine sahip olduğu anlaşımaktadır (Fig. 3). Kilisenin kuzeyinde ve olasılıkla kuzey nef ile organik bağlantısı bulunan bir ek mekân yer almaktadır (Fig. 12). Mekânın işlevi belirlenememekle beraber bölgede ve gene yakın kentlerde benzer uygulamaların olduğunu söylemek mümkündür.

Inciryalısı Koyu'nda ve Çövmen Tepesi eteklerinde yer alan kilise bir yapı topluluğunun öğesidir. Plan tipi olarak M.S. V.-VI. yüzyıl özelliklerini göstermektedir. Bölgede yer alan bu döneme ait benzer örnekler değerlendirildiğinde benzer türde yapı topluluklarının geniş bir alana yayıldığı ve eğer manastır yapı topluluğu ise, manastır mülkiyet sınırlarının iyice geniş tutulduğu ve bu sınırlar dâhilinde başka yapısal birimler olduğu bilinmektedir. Bu nedenle, yapı topluluğunun yeri, herhangi bir yerleşim biriminin dâhilinde olmaması ve Phaselis'e olan mesafesi göz önüne alındığında kilisenin bir manastır kilisesi olduğu anlaşılmaktadır. Ayrıca, çevredeki su kaynakları da dikkate alındığında özel bir kült alanı olduğu da söylenebilir. Bu unsurlar kilisenin ait olduğu manastır ve bu manastırın teritoryumu ile birlikte ele alınması gerektiğini göstermektedir.

25 Benzer örnekler için bk. Gemiler Ada I, II, III ve IV no'lu kiliseler, Ölüdeniz Kumsal Bazilikası, Ölüdeniz Lagün Bazilikası, Besta Koyu Kilisesi. Kazuno 1995, 407-419 Ksanthos Akropolis Kilisesi, Canbilen et al. 1996, 201229, Ksanthos Büyük Bazilika, Sodini 1980, 119-148. Olympos 1 no'lu kilise; Gökalp - Yıldırım 2010, 367387. 
Adak et al. 2005

Altripp 2006

Bayburtluoğlu 1983

Bayburtluoğlu 1984

Bayburtluoğlu 1985

Brandes 1989

Canbilen et al. 1996

Effenberger - Kunze 1995

Foss 1996

Geppert 2000

Gökalp - Yıldırım 2010

Grossmann - Severin 2003

Hild 2004

Işık 1995

Kazuno 1995

Mansel 1978

Mergen 2011

Peschlow 1984

Peschlow 2007

Rott 1908

Sodini 1980

Schäfer 1971

Schäfer 1981

Uluçam 1991

Vann et al. 2001

\section{BIBLIYOGRAFYA}

M. Adak, N. Tüner Önen - S. Şahin, "Neue Inschriften aus Phaselis I". Gephyra 2 (2005) 1-20.

M. Altripp, "Die Basilika von Korba in Lykien". Ed. F. Kolb, Lykische Studien 7: Die Chora von Kyaneai, Tübinger Althistorische Studien 2. Tübingen (2006) 75-88.

C. Bayburtluoğlu, "1982 Phaselis Kazısı Raporu”. KST V (1983) 181-189.

C.Bayburtluoğlu, "1983 Phaselis Kazısı Raporu”. KST VI (1984) 301-312.

C. Bayburtluoğlu, "Phaselis Kazısı Raporu”. KST VII (1985) 373-386.

Wolfram Brandes, Die Städte Kleinasiens im 7. und 8. Jahrhundert (Berliner Byzantinistische, Arbeiten 56). Berlin 1989.

H. Canbilen, P. Lebouteiller - J. Sodini, "La Basilique de L'Acropole Haute de Xanthos". Anatolia Antiqua IV (1996) 201-229.

A. Effenberger - M. Kunze "Kent Bazilikası, Patara 93". KST XVI/2 (1995) 253-282.

C. Foss, Cities, Fortresses and Villages of Byzantine Asia Minor. Hampshire 1996.

K. Geppert "Bericht über die Arbeiten in Korba" Ed. F. Kolb, Die Siedlungskammer des Yavu-Berglandes Bericht über die Ergebnisse der Feldforschungs Kampagne 1995 auf dem Territorium der Zentrallykischen Polis Kyaneai, Lykische Studien 5. Bonn (2000) 33-39.

Z. D. Gökalp - Ş. Yıldırım, "Lykia Olympos'unda Bir Restitüsyon Denemesi". Adalya XIII (2010) 367-387.

S. Grossmann- H. G. Severin, Frühchristliche und Byzantinische Bauten im Südöstlichen Lykien. Tübingen 2003.

F. Hild, "Lykien in den Notitiae Episcopatuum". Jahrbuch der Österreichischen Byzantinistik 54 (2004) 1-17.

F. Işık, "Patara 1993". KST XVI/2 (1995) 253-282.

A. Kazuno "Survey of The Early Byzantine Sites in Ölüdeniz-Gemilerada Area". AST XII (1995) 407-419.

A. M. Mansel, Side 1947-1966 Yılları Kazıları ve Araştırmalarının Sonuçları. Ankara 1978.

Y. Mergen, Olympos Antik Kenti'nin Ortaçağ Dönemi Dokusu ve Likya Bölgesi Açısından Önemi. Yayınlanmamış Doktora Tezi, Ege Üniversitesi. İzmir 2011.

U. Peschlow "Die Bischofkirche in Limyra (Lykien)". Ed. D. I. Pallas, Actes du Xle Congrès international d'archéologie chrétienne (Thessalonique 28 Septembre - 4 Octobre 1980). Thessalonique (1984) 409-421.

U. Peschlow "Befestigungen Lykischer Stadte in Spatantiker und Frühbyzantinischer Zeit". Eds. K. Dörtlük - T. Kahya, III. Uluslararası Likya Sempozyumu 07 - 10 Kasım 2005 Antalya. Sempozyum Bildirileri Cilt: I II. Antalya (2007) 601-624.

Hans Rott, Kleinasiatische Denkmäler aus Pisidien, Pamphylien, Kappadokien und Lykien. Leipzig 1908.

J. P. Sodini "Une Iconastase Byzantine a Xanthos". Actes du Colloque sur la Lycie Antiqua 27 (1980) 119-148.

J. Schäfer, "Phaselis. Beiträge zur Topographie und Geschichte der Stadt und ihrer Häfen". AA (1971) 542-561.

J. Schäfer, Phaselis. Beiträge zur Topographie und Geschichte der Stadt und ihrer Häfen.Tübingen 1981.

A. Uluçam, "Patara (Büyük Kilise) 1989”. KST XII/2 (1990) 37-55.

R. Vann, R. Hohlfelder - D. Sullivan "Survey of Aperlae in Lycia the 1998 
Wurster 1996

Season". AST XVIII/2 (2001) 285-290.

W. W. Wurster "Dynastensitz wird Römerstadt: Eine Skizze über Prozesse der Romanisierung in Lykien". Eds. F. Blakolmer, K. R. Krierer - F. Krinzinger et al., Fremde Zeiten Band I, Festschrift für Jürgen Borchhardt. Wien (1996) 161-174. 